ANDRZEJ CZYŻEWSKI

ŁUKASZ KRYSZAK

\title{
Payments under the Common Agricultural Policy as a determinant of development of different types of agricultural holdings
}

Professor Andrzej Czyżewski Poznan University of Economics and Business, Department of Macroeconomics and Agricultural Economics

Łukasz Kryszak, Ph.D. Student Poznan University of Economics and Business, Department of Macroeconomics and Agricultural Economics

\section{Introduction}

Payments under the Common Agricultural Policy (CAP) are paid through two pillars. The first pillar including mainly direct payments, supports the income of agricultural holdings. It is assumed that second pillar has got three dimensions related to modernization, investment and environmental issues. The resources in this pillar are used therefore to stimulate the economic development and to contribute to the expected structural and effective changes in food economy. In addition, these resources should subserve development of rural areas. In practice the multitude of actions taken under the Rural Development Programme (RDP) allows for classyfing them according to their primary purposes, e.g. income support, improving the quality of life in rural areas or technical equipping of the agriculture. The last one should serve the improvement in efficiency of agriculture in the highest degree (Biczkowski 2013, p.95; Rowiński 2009, p. 62).

According to the microeconomic approach one may assume that the main goal of 
agricultural producer is to maximize the income understood as a difference between receipts and costs of applying of production factors (land, work and capital). In short term view, the profitability of agricultural production is determined by price relations (price scissors), because it is impossible to improve efficiency defined as an increase in production per capital or work unit. In long term perspective, prices of agricultural products should not increase considering the limitations of demand (inflexible demand on agricultural products). Hence, the only way to improve the profitability of farms may be to increase their efficiency. In the case of a single farm it refers to an increase in production for the given amount of capital and work, while in a whole agricultural sector an excessive growth in production is not desirable considering the risk of disproportionate growth in prices (King's effect). Hence, it may be necessary to limit the employment of workforce (Rembisz 2013, pp. 23, 175). Lower employment in agriculture is possible on condition that the agrarian structure will change and the farms will undergo modernization. Both actions strictly depend on the payments and may be stimulated and limited by them. It is worth to noting that payments are important in increasing the incomes of the farm in first years of receiving the support. Furthermore, the organization of holding, its ability to adapt to market conditions as well as current situation in agroeconomy sector have a strong impact on the farms (Babuchowska, Marks-Bielska 2009). The main goal of this article is therefore to examine the impact of different types of EU payments on economic development (including efficiency) of certain types of farms, using the criterion of predominant type of farming. Since FADN data were used, only commercial farms have been taken into consideration. A period of research covers the years of 2004-2013.

\section{EU payments and economic development of farms in the light of previous research}

Thanks to the support from EU budget the technical and production level of agriculture has significantly improved. However, the competitiveness of agriculture is not the most important part of competitive advantage of Polish economy at the international level. Relatively abundant labor resources predispose this sector to more laborious method of production (Wigier 2013, p. 15). On the other hand the positive impact on competitiveness have such actions as young farmers support which accelerates a process of structural changes in agriculture (Brodecki, Cichalecka 2012 p.361). Evolving agrarian structure will lead to an increase in mechanization of agriculture while 
reducing employment at the same time. Many family farms that will not be able to reach sufficiently high income (in relation to non-agricultural income) will be forced to search for other sources of income (Wójcik 2011, p. 65). Empirical research indicated the important role of EU payments (including some RDP actions) to improving economic results of farms. The analysis using RegPOLTERMmodel (Zawalińska 2011, pp.32-35) claimed that payments (from both pillars) contribute to GDP growth and enhance the increase in real income of rural households (what which is obviously connected with income from farm, although it is not the same) of $2.38 \%$ (I pillar) and $2.39 \%$ (II pillar) respectively. However, it should be remembered that this impact differs significantly in individual voivodeships. Research on profitability of farms in some specific sectors of production (Szumiec, Borecka, Sowula-Skrzyńska 2014 pp. 293-297) show that without payments under the CAP some farms would report a loss (negative income). In the context of discussion about the role of payments for farms operating it is worth to noting the survey conducted by Zawalinska (2010, p. 102), which concerned spending of funds receiving under the CAP. Respondents declared that they spend direct payments mainly on means of production. However $30 \%$ of surveyed declared spending support on current needs and $18 \%$ on investments (e.g. machinery). The answers varied significantly in different regions. For example, in Zachodniopomorskie voivodeship $90 \%$ of responded farmers said that they spend the support on production means while in Podkarpackie and Małopolskie voivodeships, where large farms dominate, 68 and $50 \%$ of farmers (respectively) claimed that they use payments on current needs.

Considering the need of improving the efficiency of farms as well as a whole sector, payments from II pillar played a particularly important role. The Rural Development Programme for 2007-2013 consisted of 5 axes (MRIRW 2007), however in the context of these consideration the first and the third axis were particularly important. The first axis dealt with the improvement of competitiveness of agriculture and forest sector, and the third referred to the quality of life in rural areas and diversification of rural economy. In the first axis there were actions to improve the quality of human capital (vocational training for farmers and foresters, use of advisory service), action: facilitating the start of young farmers that would lead to structural changes in rural areas and assuming farms by younger and well-educated persons, and modernization of farms, which would lead to the improvement in efficiency through more effective use of available production factors. According to the data gathered at the end of 2015 (data from ARIMR 2016), in the latter action the total payments

Payments under the Common Agricultural Policy as a determinant of development of different types of agricultural holdings 
for farms amounted to 10.2 PLN billion. Young farmers received $3.1 \mathrm{bln}$, while almost 127 PLN mln was devoted to vocational training. The activity related to support agricultural producers group is also worth mentioning, because it seems that increasing and stabilising the income of agricultural producers should involve the development of vertical and horizontal integration in agriculture (Czyżewski, Kryszak 2015, pp. 26-28). Over 805 bln PLN was allocated to this activity. The actions under the third axis, such as diversification in non-agricultural activity or creating and development of microfirms served in turn the socio-economic development of rural areas and also the limitation of fictitious employment in agricultural holdings. It was consistent with the postulate of improvement of efficiency through reducing the workload. Within these two actions the expenditures reached about 4 bln PLN. Research on impact of actions from II pillar of RDP on economic development of farms was conducted by Zieliński and Sobierajewska (2012, pp. 81-95). They focused on the support of young farmers and modernization of farms. It turned out that farms leaded led by farmers who used the first of these activities reached in 2009-2010 higher value added by 56\% whereas farms that did not use this instrument (despite meeting requirements) increased their value added only by $15.2 \%$. Significant differences were observed also in gain management and profitability of own work. Summing up the current discussion it should be noted that economic situation of farms has improved thanks to the payment, at least in short term.

\section{Differences in the use of payments in different types of farms}

EU payments contribute to the economic development of farms, e.g. since they have an impact on income growth. However, the excessive dependence on payment in long term is not desirable because it may block the structural changes. When assessing the role of payments for the development of different types of farms, it should be investigated what part of income accounted for payments (both on investments and current operations) in the particular types of farms (table 1). This refers to net income (income from family farming).

In the analysed period the largest share of payments in income is observed in farms breeding grazing livestock. The average number of payments was $106,6 \%$. The data also presents that in five cases the numbers exceeded $100 \%$. The data indicate that those types of farms highly rely on the subsidies. If payments were excluded these farms would record a loss (negative income) and its operating would be irrational from the economic point of view. The high share of payments 
in income may be perceived also in mixed farms (in analysed period it was $72.9 \%$ on average) and holdings with fieldcrops (67.7\%). Highly limited dependence on payments have been observed in horticulture farms as well as the farms dealing with other types of permanent crops and granivores. In the case of the horticultures the share of payments in income was only $8.3 \%$. These data claim that more specialistic farms show generally a higher economic potential. Hence, the role of payments is less in their cases ${ }^{1}$. On the other hand one can say that without the support some farms would not operate, even if their role for culture, natural environment and healthy food was recognised. (e.g. farms located in mountains). When analysing the data in the table 1 one should pay attention to stabilising role of the payments. In favourable for agriculture 2007 year, the share of payments in incomes was relatively low in all types of farms, despite the absolute growth in value of payments. In turn, during the crisis in 2009 this share was high and in three types of farms exceeded $100 \%$.

Table 1. Share of subsidies on investments and current operating in family net farm income in average Polish FADN farms in 2004-2013 by predominant type of farming (\%)

\begin{tabular}{c|c|c|c|c|c|c|c}
\hline \multirow{2}{*}{ Years } & \multicolumn{7}{|c}{ Predominant type of farming } \\
\cline { 2 - 8 } & Fieldcrops & $\begin{array}{c}\text { Horti- } \\
\text { culture }\end{array}$ & $\begin{array}{c}\text { Other } \\
\text { permanent } \\
\text { crops }\end{array}$ & Milk & $\begin{array}{c}\text { Other } \\
\text { grazing } \\
\text { livestock }\end{array}$ & $\begin{array}{c}\text { Grani- } \\
\text { vores }\end{array}$ & Mixed \\
\hline 2004 & 41.4 & 3.8 & 17.2 & 29.7 & 70.3 & 20.6 & 41.9 \\
\hline 2005 & 61.4 & 4.2 & 11.4 & 29.0 & 85.0 & 26.0 & 56.3 \\
\hline 2006 & 63.3 & 6.8 & 14.6 & 42.4 & 87.5 & 38.9 & 65.6 \\
\hline 2007 & 42.8 & 6.3 & 13.0 & 34.4 & 73.1 & 39.7 & 58.6 \\
\hline 2008 & 83.3 & 9.3 & 36.5 & 49.8 & 120.4 & 45.6 & 92.2 \\
\hline 2009 & 115.2 & 7.9 & 64.2 & 73.8 & 182.6 & 29.7 & 113.7 \\
\hline 2010 & 69.8 & 8.9 & 27.3 & 48.9 & 135.3 & 36.0 & 81.9 \\
\hline 2011 & 72.4 & 16.5 & 22.8 & 42.4 & 99.5 & 31.4 & 72.7 \\
\hline
\end{tabular}

1 One should remember that the majority of payments are those connected with area of farm which is relatively small in horticulture farms.

Payments under the Common Agricultural Policy as a determinant of development of different types of agricultural holdings 


\begin{tabular}{c|c|c|c|c|c|c|c}
\hline 2012 & 60.0 & 11.2 & 28.5 & 47.9 & 105.8 & 30.6 & 72.8 \\
\hline 2013 & 78.8 & 11.9 & 32.6 & 47.0 & 121.3 & 26.9 & 90.3 \\
\hline average & 67.7 & 8.3 & 26.2 & 44.2 & 106.6 & 33.2 & 72.9 \\
\hline
\end{tabular}

Source: own study based on FADN database (variables SE406, SE420, SE605)

If one assume that payments should contribute to an increase in economic efficiency of farms, the payments should have more investment character. Data concerning the investment subsidies in relation to total subsidies are presented in table 2. Because of the minimal use of investment payments in 2004-2005, presented data refer to the 2006-2013 period.

Table 2. Share of subsidies on investments in all subsidies in average Polish FADN farms in 2006-2013 by predominant type of farming (\%)

\begin{tabular}{|c|c|c|c|c|c|c|c|}
\hline \multirow[b]{2}{*}{ Years } & \multicolumn{7}{|c|}{ Predominant type of farming } \\
\hline & Fieldcrops & $\begin{array}{l}\text { Horti- } \\
\text { culture }\end{array}$ & $\begin{array}{c}\text { Other } \\
\text { permanent } \\
\text { crops }\end{array}$ & Milk & $\begin{array}{c}\text { Other } \\
\text { grazing } \\
\text { livestock. }\end{array}$ & Granivores & Mixed \\
\hline 2006 & 2.3 & 4.5 & 12.9 & 0.7 & 0.4 & 0.6 & 0.6 \\
\hline 2007 & 2.0 & 5.6 & 4.9 & 6.7 & 3.0 & 6.0 & 3.0 \\
\hline 2008 & 2.8 & 13.6 & 10.2 & 7.5 & 2.6 & 6.7 & 3.3 \\
\hline 2009 & 2.4 & 8.7 & 7.0 & 5.4 & 1.7 & 8.3 & 2.6 \\
\hline 2010 & 3.0 & 11.2 & 10.1 & 7.8 & 1.9 & 8.7 & 2.8 \\
\hline 2011 & 3.1 & 8.6 & 9.5 & 7.0 & 2.6 & 7.8 & 2.8 \\
\hline 2012 & 3.4 & 14.8 & 10.3 & 7.6 & 3.1 & 7.9 & 2.9 \\
\hline 2013 & 3.3 & 14.2 & 8.5 & 7.8 & 2.8 & 7.2 & 2.8 \\
\hline average & 2.8 & 10.1 & 9.2 & 6.3 & 2.3 & 6.7 & 2.6 \\
\hline
\end{tabular}

Source: own study based on FADN database FADN (variables SE406, SE605

Subsidies on investments played the most important in horticulture farms (they accounted for $10,1 \%$ of all subsidies on average). That is the type of the farm in which payments accounts for relatively small portion of income. Subsidies on 
investments were also important to farms with permanent crops and granivores. Relatively little importance of subsidies on investments might be observed in mixed farms as well as in those which have fieldcrops and breeding grazing livestock (share of processed payments was $2.6 ; 2.8$ and $2.3 \%$ respectively). These type of farms had a big share of total payments in income at the same time. Such data may therefore indicate that economic efficiency in these types of farm is low and the dynamic of investment process is not sufficient enough. In 2009, the lower share of investment payment in total payments could be observed only in three of seven types of farms. Therefore it is possible to assume that investing activities in agriculture depended not solely on current situation in economy but mainly on the availability of funds within the framework calls for specific actions financed by II pillar of CAP.

\section{The role of EU payments for accumulation processes in agricultural holdings}

In long term the investments should stimulate the growth in production potential of the farm. The continuity of investment process and financing these investments depends on saving income (profit) called accumulation. It is, along with the reproduction, one of the main determinants of the development process (Grzelak 2014, p. 305). Formally accumulation should be understood as a change in net worth of farm in the end of year in comparison to the data recorded at beginning of the year. In the context of this article it may be necessary to compare the real (RA) and theoretical (TA) accumulation (table 3), wherein the latter is calculated by excluding the size of operational and investment support from real accumulation. Comparing these two values, one should highlight the role of payments in incidence and intensity of accumulation processes. To enable more objective comparisons of accumulation change in time, downloaded data, previously presented in euro were recalculated into PLN so the influence of exchange rate was excluded.

In 2004-2013 generally positive values of real accumulation were reported, and thus it caused that farms have increased their net worth. The negative value of real accumulation (loss in net worth) was only observed in 2005 in most types of farms (exactly in five types). Moreover, negative real accumulation was reported in the farms engaged in permanent crops (years 2009, 2010, 2013) and among horticulture farms in 2010. The data presented in the table indicate that accumulation processes are largely dependent on the current situation. It is because the intensity of the process was especially high in 2007 and 2011 which were favourable for the agriculture. Nevertheless, one should note that

Payments under the Common Agricultural Policy as a determinant of development of different types of agricultural holdings 
positive real accumulation was also reported in 2008-2009. According to Grzelak (2014, p. 307) such situation could be caused by the effects of investment activity undertaken in the previous period. It should be also noted that the dynamic of changes in net worth depended on growing land prices. Considering such effect would probably decrease the accumulation level in each year.

Table 3. Value of real and theoretical accumulation in average Polish FADN farms in years 2004-2013 by predominant type of farming (in thous. PLN)*

\begin{tabular}{|c|c|c|c|c|c|c|c|c|c|c|c|c|c|c|}
\hline \multirow[t]{3}{*}{ Years } & \multicolumn{14}{|c|}{ Predominant type of farming } \\
\hline & \multicolumn{2}{|c|}{ Fieldcrops } & \multicolumn{2}{|c|}{$\begin{array}{l}\text { Horti- } \\
\text { culture }\end{array}$} & \multicolumn{2}{|c|}{$\begin{array}{l}\text { Other } \\
\text { permanent } \\
\text { crops }\end{array}$} & \multicolumn{2}{|c|}{ Milk } & \multicolumn{2}{|c|}{$\begin{array}{c}\text { Other } \\
\text { grazing } \\
\text { livestock. }\end{array}$} & \multicolumn{2}{|c|}{$\begin{array}{l}\text { Grani- } \\
\text { vores }\end{array}$} & \multicolumn{2}{|c|}{ Mixed } \\
\hline & RA & TA & RA & TA & $\mathbf{R A}$ & TA & RA & TA & RA & TA & RA & TA & RA & TA \\
\hline 2004 & 24.0 & 4.0 & 24.6 & 22.9 & 30.7 & 27.3 & 19.0 & 9.3 & 4.6 & -2.5 & 18.6 & 9.5 & 40.1 & 32.2 \\
\hline 2005 & -19.2 & -38.9 & 5.5 & 3.5 & -11.8 & -14.6 & 1.5 & -7.8 & -4.4 & -12.1 & -10.2 & -20.4 & -10.1 & -18.4 \\
\hline 2006 & 15.9 & -11.8 & 9.2 & 5.9 & 5.9 & 1.1 & 17.9 & 1.7 & 8.2 & -6.7 & 10.2 & -5.4 & 6.2 & -6.9 \\
\hline 2007 & 45.7 & 18.1 & 20.8 & 16.7 & 9.4 & 3.0 & 32.1 & 15.1 & 17.1 & 1.8 & 22.1 & 7.1 & 16.4 & 2.3 \\
\hline 2008 & 23.5 & -13.3 & 15.6 & 10.7 & 25.6 & 17.8 & 13.2 & -6.1 & 1.6 & -16.9 & 9.3 & -9.1 & 2.6 & -14.5 \\
\hline 2009 & 18.1 & -14.5 & 19.3 & 14.2 & -23.6 & -33.6 & 8.0 & -15.7 & 8.3 & -17.6 & 37.2 & 8.6 & 6.8 & -13.2 \\
\hline 2010 & 11.1 & -22.2 & -2.3 & -8.2 & -3.7 & -14.0 & 16.1 & -10.0 & 1.5 & -24.6 & 24.7 & -7.8 & 5.2 & -15.0 \\
\hline 2011 & 21.6 & -12.7 & 5.7 & -3.9 & 18.0 & 6.8 & 41.9 & 12.6 & 7.0 & -18.5 & 52.6 & 17.7 & 14.3 & -6.7 \\
\hline 2012 & 19.9 & -14.3 & 4.3 & -1.7 & 8.3 & -4.3 & 25.6 & -2.2 & 3.9 & -21.4 & 31.3 & -1.7 & 6.8 & -13.5 \\
\hline 2013 & 9.4 & -26.2 & 6.2 & -2.2 & -5.8 & -19.8 & 21.5 & -7.8 & 3.7 & -24.8 & 16.6 & -13.7 & 2.1 & -20.0 \\
\hline
\end{tabular}

* Data in euros converted into PLN according to the average exchange rate available in the database FADN

Source: own study based on FADN database FADN (variables SE506, SE605)

The values of theoretical accumulation were significantly different. Only in 2007 it was possible to report positive theoretical accumulation in all types of farms. Additionally in most types of farms positive theoretical accumulation appeared in 2004 and in 3 types of farms in 2011. In 2010-2013 the phenomenon of 
negative theoretical accumulation was common in all types of farms, wherein it occurred significantly in 2013. During the crisis period, only horticulture farms scored positively. In this type of farm even in 2008-2009 period the positive theoretical accumulation was reported. It was caused by relatively smaller role of EU payments in these farms. In turn, among farms engaged in grazing livestock the positive theoretical accumulation occurred only in 2007. The comparison of data concerning the real and theoretical accumulation insist on important role of EU payments for the process of growth of net worth among agricultural holdings. The role of the EU payments is crucial and is still strengthening its position, as evidenced by the widespread phenomenon of negative theoretical accumulation after 2010. Therefore it is possible to state that payments maintain and condition the accumulation processes (Grzyb, Kryszak 2016).

The increasing resources of equity should lead to growth in economic strength of farms. It is usually an equivalent to the increase in the size of the farm. The economic size of the farm is closely connected with a better position on the market. In addition, larger farms can more efficiently use their resources, especially the labor factor. The question then arises, how the processes of accumulation affect the growth of the economic size of farm. In FADN database it is expressed in euro and is related to the standard output. The impact of accumulation on growth of economic size may be calculated with the use of accumulation efficiency ratio understood as an absolute change in economic size divided by value of accumulation (table 4). Again, data given in Euro were recalculated and expressed in PLN. The interpretation of this ratio is only justified in case of positive accumulation. Hence, in case of negative accumulation the ratio value was not calculated.

Table 4. The efficiency of real accumulation in average Polish FADN farms in years 2004-2013 by predominant type of farming (in PLN)

\begin{tabular}{c|c|c|c|c|c|c|c}
\hline Years & $\begin{array}{c}\text { Field- } \\
\text { crops }\end{array}$ & $\begin{array}{c}\text { Horti- } \\
\text { culture }\end{array}$ & $\begin{array}{c}\text { Other } \\
\text { permanent } \\
\text { crops }\end{array}$ & Milk & $\begin{array}{c}\text { Other } \\
\text { grazing } \\
\text { livestock. }\end{array}$ & $\begin{array}{c}\text { Grani- } \\
\text { vores }\end{array}$ & Mixed \\
\hline 2005 & $\mathrm{x}$ & -2.25 & $\mathrm{x}$ & -6.45 & $\mathrm{x}$ & $\mathrm{x}$ & $\mathrm{x}$ \\
\hline 2006 & -0.12 & -1.82 & -0.18 & -0.03 & -0.57 & -0.81 & -0.04 \\
\hline 2007 & -0.15 & 1.75 & 0.15 & 0.04 & 0.26 & -0.39 & -0.05 \\
\hline 2008 & -0.16 & -1.34 & -0.11 & -0.22 & -1.02 & -0.82 & -0.85 \\
\hline
\end{tabular}

Payments under the Common Agricultural Policy as a determinant of development of different types of agricultural holdings 


\begin{tabular}{c|c|c|c|c|c|c|c}
\hline 2009 & 0.87 & 1.64 & $\mathrm{x}$ & 5.06 & 3.59 & 5.96 & 3.56 \\
\hline 2010 & -0.42 & $\mathrm{x}$ & $\mathrm{x}$ & -0.34 & -9.17 & -1.96 & -1.39 \\
\hline 2011 & 0.06 & 1.21 & 0.09 & 0.23 & -0.72 & 0.49 & 0.12 \\
\hline 2012 & 0.02 & 2.18 & 0.33 & 0.03 & 0.88 & -0.62 & -0.01 \\
\hline 2013 & 0.21 & 2.88 & $\mathrm{x}$ & 0.15 & 1.75 & 0.46 & 2.26 \\
\hline
\end{tabular}

Source: own study based on FADN database FADN (variables SE005, SE506)

In periods when the positive changes in accumulation were observed, the growth in economic size was not always reported. Nevertheless in a whole period one may observe an increase of economic size of farm, however this process was unstable. This should be linked to strong influence of current situation on the agricultural sector. The most efficient processes of accumulation were observed in horticulture farms. In the whole period (under the condition of positive accumulation) the increase of equity by 1 PLN generated (on average) the growth of economic size by 0.53 PLN. Again, the data suggest that these horticultural farms are characterized by relatively high performance. The lowest efficiency of accumulation may be observed, in turn, in farms that are engaged in other grazing livestock. The average efficiency of accumulation in the analysed period was -0.63 there. However, the average value was influenced by the economic situation in 2010 when the growth in equity by 1 PLN was accompanied by the loss in economic size by more than 9 PLN. When interpreting data in table it is crucial to note that the highest efficiency of accumulation in most types of farms were reported in 2009. That year the processes of accumulation gradually decelerated, however the growth in economic size of farms was relatively high. It could be caused by the processes of the growth in economic size which were started in previous years.

\section{Change in profitability of farms on the example of ROE indicator}

Previous discussion proved the important role of payments in the process of creating income and accumulation. It is also worth to checking whether the introduction of payments in Polish agriculture improved profitability of the farms. Analyzing the economic situation of the company usually a ratio analysis is used. Its purpose is to analyze the profitability of the company, particularly the 
return on equity, assets and sales. From the dynamic approach perspective one may assume that profitability increases when the operating results (e.g. income or profits) are growing faster than the amount of capital involved, assets or sales volume. From the farms point of view particularly important are ROA (return on assets) and ROE (return on equity) indicators. The second one is crucial to owners of capital in the economy. One may say that the economic activity (including agriculture) is profitable if the value of ROE exceeds the interest rate on long-term bank deposits (Gołębiewska 2010, p. 168). The values of ROE in the studied types of farms are provided in Figure 1 . The adapted category of profit is the net farm income. One should remember that this solution is not ideal due to the fact that the own work is not marked off in this indicator (Grzyb, Kryszak 2016).

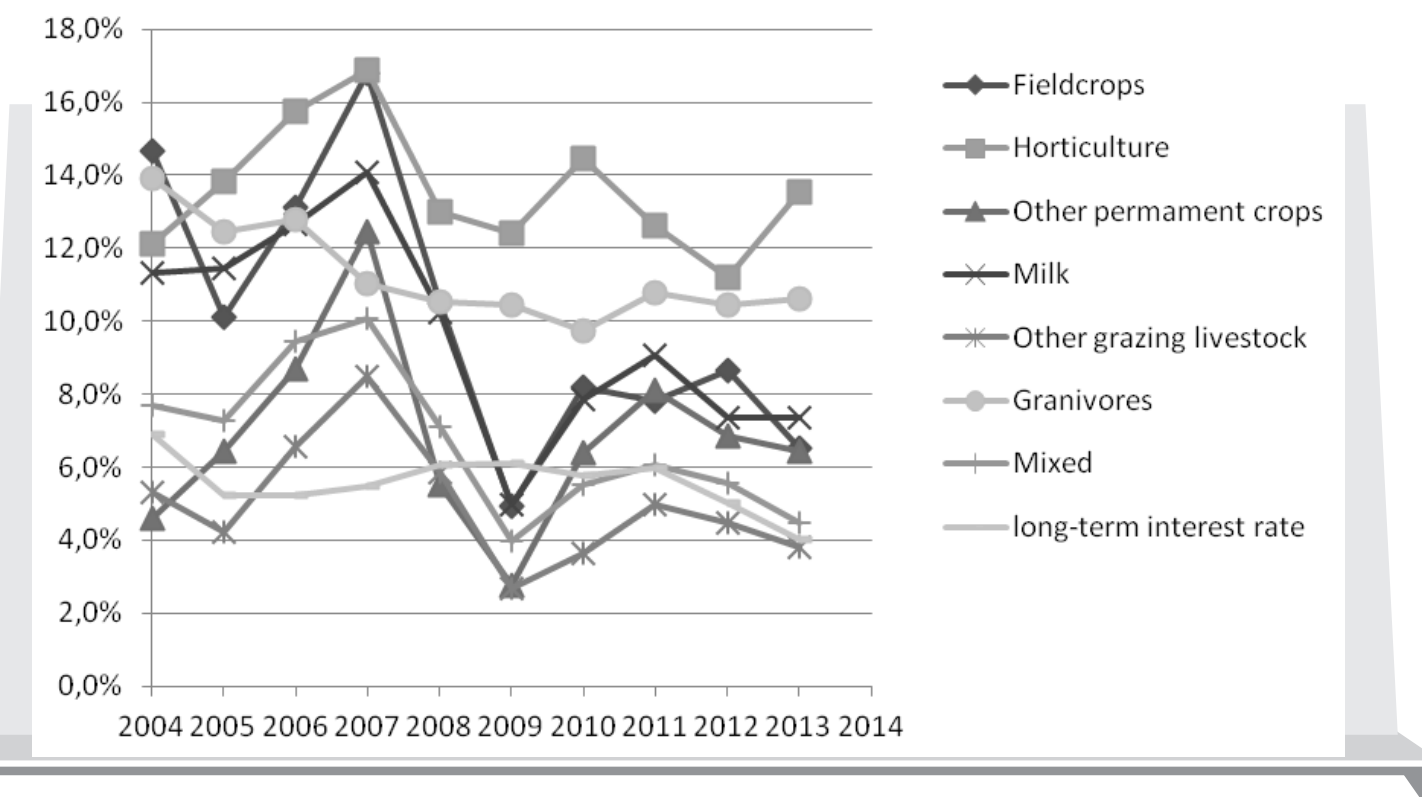

Figure 1.ROE values in average Polish FADN farms in years 2004-2013 by predominant type of farming

Source: own study based on FADN database FADN (variables SE420, SE501) and Eurostat

The analysis of return of equity (ROE) indicates that there are significant differences in its level in different types of farms. The highest level of profitability was reported in farms engaged in horticulture and among farms that breeding granivores. For example 16.9\% the value of ROE in 2007 among horticulture farms means that each euro of engaged equity has generated about 0,17 euro of

Payments under the Common Agricultural Policy as a determinant of development of different types of agricultural holdings 
net income. The year 2007 was a period of particular prosperity in agriculture, however even then the profitability of farms engaged in grazing livestock was twice lower and reached $8.5 \%$. These farms, as well as farms with permanent crops, were characterized by the lowest levels of ROE indicator which were in some years lower than average long-term interest rate. This situation was caused rather by relatively low income in these farms, than by high value of the equity engaged in the process. He The observation of the formation of ROE ratios in different types of farms indicates that it is impossible to observe any trend changes in profitability. It varies under the influence of economic situation. After the accession to EU in 2004 the profitability was increasing due to the prosperous conditions and it reached its peak in 2007. Then it sharply declined in 2008-2009 and from 2010 it has started to grow again. To the lesser extent, these phenomena are related to the farms dealing with granivores where profitability remained relatively stable. The fact that the ROE after 2010 are lower than they were before the crisis of 2009 can be attributed to the previously discussed processes of accumulation. As a result of these processes, it is expected that despite the increase in farms income the profitability of the unit will decrease due to the growing equity (ROE denominator). In other words, unit profit from production may be lower despite an increase in total profit.

\section{Conclusions}

Payments under the CAP complemented the landscape of Polish countryside and agriculture. Currently, it is difficult to imagine the functioning of the agricultural sector without this support. The results of research cited in this article indicate significant effects of payments under the two pillars to the development of farms and their profitability. This influence is different to different types of the farms. The particular role of payments may be observed in less efficient farm, e.g. engaged in breeding grazing livestock. On the one hand such a phenomenon should be assessed positively because payments become a kind of safety net for those farms. On the other hand the social character of payments may discourage from improving the efficiency and may limit the indispensable structural change. Payments become therefore a substitute of changes. Similarly, data concerning the share of investment payment in total payments indicate that using investment payment is more widespread in farms that are in better situation, e.g. horticulture farm which are characterised by more capital-intensive method of production. The availability of payments allows for the processes of accumulation, that is growth in net worth. The increase in 
capital stock should contribute to the growth of the economic potential of farms, including the growth of their economic size, although this process involves periodic variation. Intensification of the processes of accumulation due to the mechanisms of the CAP will lead to an increase in agricultural income. This growth may be slower than the growth of equity, which will result in a decrease in the efficiency of the unit.

\section{Summary}

Common Agricultural Policy as a economic determinant of development of different types of agricultural holdings

The main aim of this article was to investigate the influence of payments under the CAP on economic development of different types of farms. The main source of data was FADN database. A period of research covers the years of 2004-2013.The article referred to previous results of research in the field of payments and its role for the economic situation of agricultural holdings. Then the share of payments in agricultural income was examined as well as the use of subsidies on investments. The process of accumulation, both in real and theoretical approach, and influence of this phenomenon on change of economic size were also presented. In addition the paper analysed the changes in return on equity in order to show the changes in economic efficiency of farms. The analyses that were conducted showed a significant role of payments in the formation of incomes and accumulation. On the other hand payments may lead to decrease in efficiency. In long term there is a risk that dependence on payments in functioning of farm will be excessive.

Keywords: CAP, agricultural income, accumulation, return on equit, farm profitability.

\section{Streszczenie}

Płatności WPR jako determinanta ekonomiczna rozwoju różnych typów gospodarstw rolnych

Głównym celem artykułu było zbadanie wpływu płatności w ramach WPR na rozwój różnych typów gospodarstw rolnych. Głównym źródłem danych była baza danych FADN. Zakres czasowy badań obejmował lata 2004-2013. W artykule przywołano

Payments under the Common Agricultural Policy as a determinant of development of different types of agricultural holdings 
dotychczasowe wyniki badań w zakresie roli płatności dla sytuacji ekonomicznej gospodarstw. Następnie poddano analizie udział płatności w kształtowaniu dochodów gospodarstw rolnych, jak też wykorzystanie płatności o charakterze inwestycyjnym. Zaprezentowane zostało też zjawisko akumulacji w ujęciu rzeczywistym i teoretycznym oraz wpływ tego procesu na wzrost wielkości ekonomicznej gospodarstw. Dodatkowo przedstawiono zmiany w kształtowaniu się wskaźnika rentowności kapitałów własnych w celu zobrazowania zmian w efektywności ekonomicznej gospodarstw. Prowadzone analizy dowiodły istotnej roli płatności w kształtowaniu dochodów i procesów akumulacji. Z drugiej strony płatności mogą przyczyniać się do spadku efektowności, a w dłuższym okresie istnieje ryzyko nadmiernego uzależnienia funkcjonowania gospodarstw od otrzymywania dopłat.

\section{Słowa}

kluczowe: WPR, dochody rolnicze, akumulacja, rentowność kapitatów własnych, dochodowość gospodarstw.

\section{References}

1. Babuchowska K., Marks-Bielska R. (2009), Wsparcie dochodów rolników w formie doptat bezpośrednich, [in:]: Ekonomika i Organizacja Gospodarki Żywnościowej, Zeszyty Naukowe SGGW, No. 75.

2. Biczkowski M. (2013), Przestrzenna alokacja wsparcia finansowego $z$ instrumentów wspólnej polityki rolnej $i$ ich wptyw na rozwój społecznogospodarczy obszarów wiejskich, [in:] Acta Universitatis Lodziensis Folia geographica socio-oeconomica 13, Wydawnictwo Uniwersytetu Łódzkiego.

3. Brodecki P., Cichalewska P. (2012), Wpływ Programu Rozwoju Obszarów Wiejskich 2007-2013 na konkurencyjność polskiego rolnictwa, [in:] Studia Iuridica Agraria, Tom 10, Uniwersytet w Białymstoku- Wydział Prawa, Białystok.

4. Czyżewski A., Kryszak Ł. (2015), Relacje cenowe w rolnictwie polskim a dochodowość gospodarstw rolnych $i$ gospodarstw domowych rolników, Problemy Rolnictwa Światowego, Tom 15 (30), Iss. 3, Zeszyty Naukowe SGGW w Warszawie, Wydawnictwo SGGW, Warszawa.

5. Gołębiewska B. (2010), Organizacyjno-ekonomiczne skutki zróżnicowania powiazań gospodarstw rolniczych z otoczeniem. Wydawnictwo SGGW.

6. Grzelak A. (2014), Wybrane zagadnienia dotyczace akumulacji i reprodukcji majątku gospodarstw rolnych w Polsce w świetle wyników rachunkowości rolnej $(F A D N)$, Przegląd Zachodniopomorski Rocznik XXIX, Iss. 3, V.2 
7. Grzyb A., Kryszak Ł. (2016), Płatności w ramach wspólnej polityki rolnej i efektywność ekonomiczna różnych typów gospodarstw rolnych w polsce po 2004 roku. Wspótzależności wybranych zjawisk, [in:] Dylematy Wspólnej Polityki Rolnej. Wydawnictwo KPSW. Bruksela-Bydgoszcz-Poznań.

8. Ministerstwo Rolnictwa i Rozwoju Wsi (2007), Program Rozwoju Obszarów Wiejskich na lata 2007-2013, Warszawa.

9. Rembisz W. (2013), Kwestie ryzyka, cen, rynku, interwencji i stabilności dochodów w rolnictwie, Wyd. Vizja Press \& IT, Warszawa.

10. Rowiński J. (2009), Program rozwoju obszarów wiejskich 2007-2013 („PROW-2013"), [in:] Polityki europejskie, Finanse i Marketing, No. 1 (50), Wydawnictwo SGGW, Warszawa.

11. Szumiec A., Borecka A., Sowula-Skrzyńska E. (2014), Wptyw doptat na efektywność ekonomiczna produkcji ekologicznego mleka w gospodarstwach objętych mechanizmami wspólnej polityki rolnej Unii Europejskiej. Roczniki Naukowe Stowarzyszenia Ekonomistów Rolnictwa i Agrobiznesu, 16 (4).

12. Wigier M. (2013), Wptyw polityki rolnej na zmiany strukturalne w rolnictwie, Zagadnienia Ekonomiki Rolnej 2013, No. 4, IERiGŻ, Warszawa.

13. Wójcik G. (2011), Wspólna Polityka Rolna i jej wptyw na rozwój rolnictwa i obszarów wiejskich po akcesji w Unii Europejskiej, w: Wiadomości Zootechniczne, R. XLIX (2011), 2, Instytut Zootechniki Państwowy Instytut Badawczy, Kraków.

14. Zawalińska K. (2010),Regionalne zróżnicowanie absorpcji wsparcia unijnego dla polskiej wsi i jego skutki dla rozwoju społeczno-gospodarczego kraju, [in:] Stanny, M., Drygas, M. (eds.), Przestrzenne, społeczno-ekonomiczne zróżnicowanie obszarów wiejskich w Polsce, IRWiR PAN, Warszawa.

15. Zawalińska K. (2011), Wptyw WPR na rozwój gospodarczy regionów Polski, [in:] Nurzyńska, I., Drygas, M. (eds.), Rozwój obszarów wiejskich w Polsce. Diagnozy strategie, koncepcje polityki, IRWiR PAN, Warszawa.

16. Zieliński M., Sobierajewska J. (2012), Efekty gospodarstw rolnych korzystajacych $z$ pomocy $w$ ramach PROW 2007-2013. Zagadnienia wybrane, in: Zagadnienia Ekonomiki Rolnej 2 (321), IERiGŻ PIB, Warszawa.

17. Website: http://www.arimr.gov.pl/pomoc-unijna/wdrazane-programyi-dzialania-dane-liczbowe/ program-rozwoju-obszarow-wiejskich-20072013.html, ARIMR (15.02.2016 - access date). 